ISSN: 2581-8341

Volume 03 Issue 12 December 2020

DOI: 10.47191/ijesrr/V3-i12-05, Impact Factor: 6.595

IJCSRR@ 2020

www.ijcsrr.org

\title{
Helicobacter Pylori Infection: Causes, Diagnosis and Treatment
}

\author{
Rahul Rao ${ }^{1}$, Tanya Datta ${ }^{2}$, Shivali Sharma ${ }^{3}$ \\ 1,2,3 Sri Raghavendra college of Pharmacy, Bangalore, India
}

\begin{abstract}
Helicobacter Pylori infection is one of the common infections worldwide. The rates of infection are reducing in both developed and developing countries, but it is still a widespread infection. In this paper we will discuss about H. pylori causes and the disease that could arise due to infection, preventive measure, precautions, treatment, and several important information regarding the infection. We also reviewed several papers and studies conducted on patients both adults and children who are affected with $\mathrm{H}$. pylori.
\end{abstract}

KEYWORDS: Helicobacter Pylori

\section{INTRODUCTION}

Helicobacter Pylori is type of bacteria which is common and grows in digestive tract and attacks stomach lining. Around sixty percent of world population has this infection in their stomach [1]. In many patients who are infected does not have any harm for them. Even though they are not harmful, but they are responsible for most of the issues in small intestine like ulcers. The bacteria that cause Helicobacter pylori is shaped in spirals, and so the name Helico means spiral, and that has led to the name Helicobacter. The infection rate is higher in developed countries than of developed countries [2]. According to several studies made by authors from different countries, H.pylori prevalence is at the rate 20\% to $40 \%$ among Europeans [3], and $90 \%$ among individuals who were born before 1950 in japan [5], and the trend has been reducing with a percentage of $2 \%$ going toward the year of born 2000's .and at $25 \%$ in USA [4]. And in the east Mediterranean region the prevalence $80 \%$ was reported [6].

Humans are primary source of H.pylori infection. Other contaminants that cause the infection are domestic cats, water, houseflies etc., $[7,8,9]$. The most common risk factor that could led to infection are overcrowding in the family, poor economic conditions, developing country, genetic factor etc., The prevalence rate of infection in the residents of developing countries is same as of African American and Asian American individuals living in USA [10]. The mode of transmission in human beings is not known but is predicted to be gastric-oral or oral. H.pylori is more prevalent in children than adults, but there are limited guidelines regarding treatment and diagnosis in children. Evidence based guidelines are required for primary care or medical providers so that they can use the guidelines for diagnosis and appropriate therapy. Keeping this in mind North American Society for Pediatric Gastroenterology and Nutrition (NASPGN) appointed H.pylori committee in order to create guidelines for children with infection. The clinical guidelines assist primary care physicians, assistants, nurse practitioners, and pediatric gastroenterologists in diagnosis and treatment of $\mathrm{H}$ pylori. These guidelines are mostly applicable to developing countries and not the countries where gastric colonization frequency is high.

With the association of $\mathrm{H}$ pylori with, gastrointestinal diseases, the pattern of occurrence of $\mathrm{H}$ pylori has changes potentially with antibiotics, and sanitization. Looks like it is prudent to determine the changing characteristic that are epidemiological of this infection. With proper information on these details, we can see improvement in clinical practice and management decisions regarding the infection.

\section{H. PYLORI-ASSOCIATED DISEASES}

Colonization due to $\mathrm{H}$ pylori is itself not a disease but it is a condition that increase the risk of developing disorders of clinical type like gastrointestinal tract and also the possibility of hepatobiliary tract. When we test for H. pylori, the test itself is of no value unless we find the underlying condition like peptic ulcer disease or for prevention of disease in subjects with gastric cancer. Even though most of the individuals who are infected with $\mathrm{H}$. pylori induce gastritis issues, but mostly clinical signs apparently develop only in minorities. Patients who are infected with $\mathrm{H}$. pylori has only chance of 10 to $20 \%$ lifetime risk of developing ulcer disease, and only $2 \%$ chance of developing gastric cancer $[11,12,13]$. In the infected people with $\mathrm{H}$. pylori the risk of these disease occurring depends on type of bacteria host, environmental factors like severity of gastritis. 


\section{International Journal of Current Science Research and Review}

ISSN: 2581-8341

Volume 03 Issue 12 December 2020

DOI: 10.47191/ijesrr/V3-i12-05, Impact Factor: 6.595

IJCSRR@ 2020

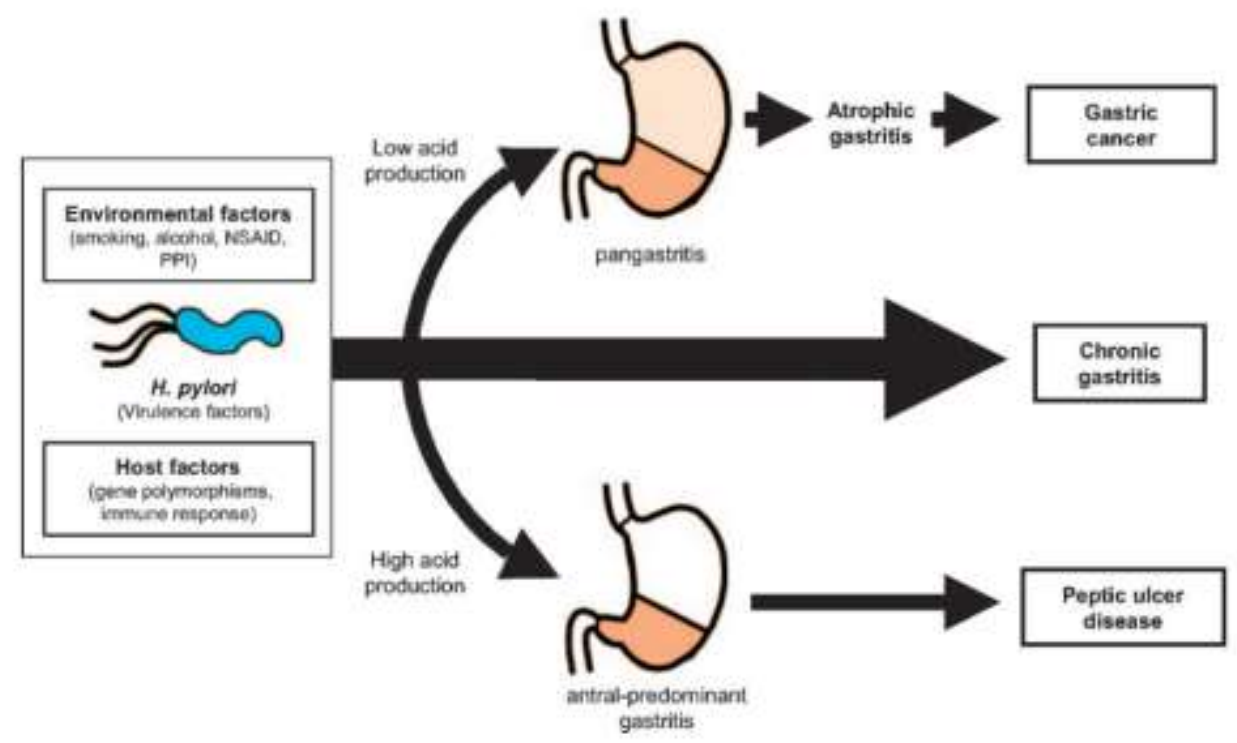

Diagram representing factors that contribute to pathology and disease outcome.[48]

Acute Gastrics: These acute infections data show the infection has mostly happened to subjects because of deliberate or inadvertent ingestion of $\mathrm{H}$. pylori or to the people who has taken some procedure with contaminated material $[14,15,16,17]$. In the recent days a human challenge model is introduced for $\mathrm{H}$. pylori infection, which allows the study on the acute infection of infection which is deliberate in healthy volunteers. And the study reports showed that, H. pylori acute phase of colonization might be associated with some symptoms like nausea, vomiting, fullness, with inflammation of pangastritis and stomach mucosa, and it is shown that these symptoms could last for several months. There is another study which was done on children with serology tests suggest that infection could possibly disappear in some patients in children. [18,19,20]. A study which is conducted on twins who are homozygotic showed that even though twins are together or separate H. pylori showed a concordance [21].

Chronic gastritis: Level of acid secretion and distribution of gastritis will have close correlation when colonization becomes persistent. This correlation is because of the effects of acid on bacterial growth. This interaction is important in determining outcome of H. pylori. In the subjects who has intact acid secretion gastric antrum is particularly colonized by H. pylori. Evaluation of gastric corpus specimens reveal few number of colonizing $\mathrm{H}$. pylori bacteria and limited chronic inactive inflammation.

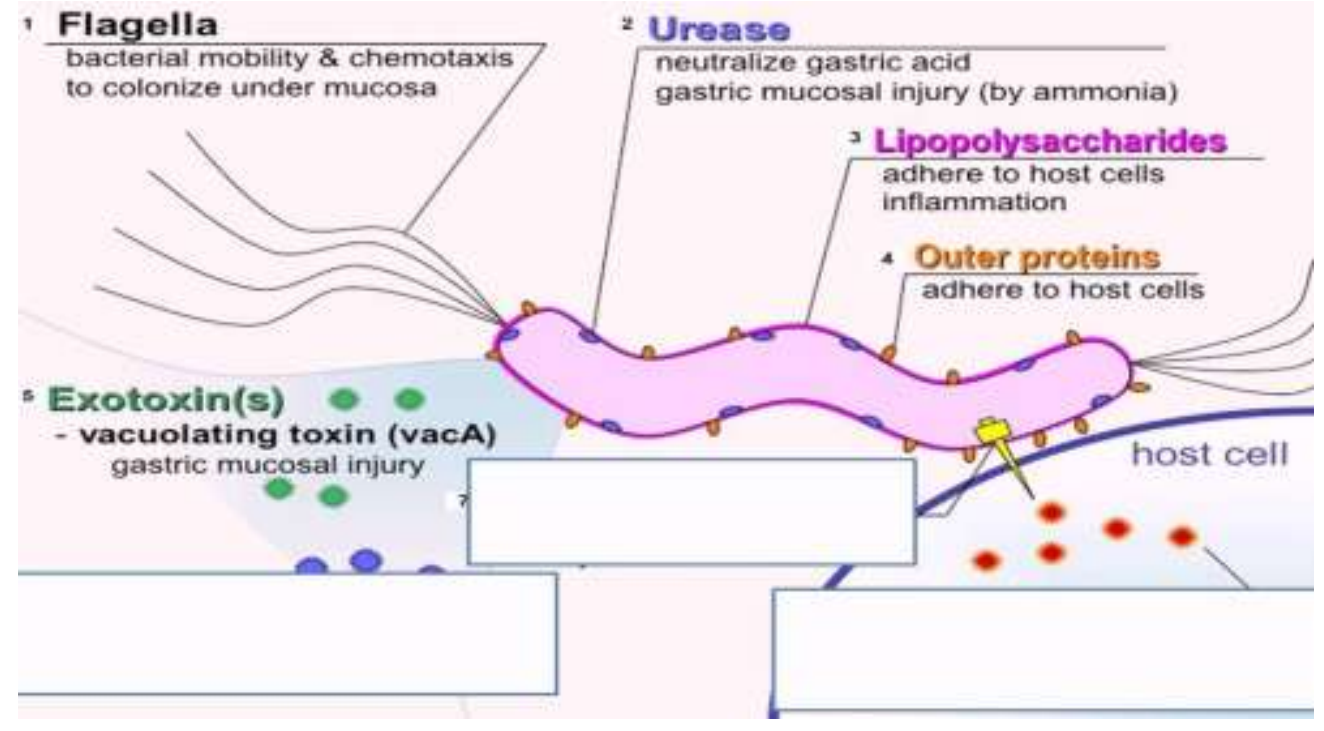

Helicobacter pylori pathgnesis [49] 


\section{International Journal of Current Science Research and Review}

ISSN: 2581-8341

Volume 03 Issue 12 December 2020

DOI: 10.47191/ijesrr/V3-i12-05, Impact Factor: 6.595

IJCSRR@ 2020

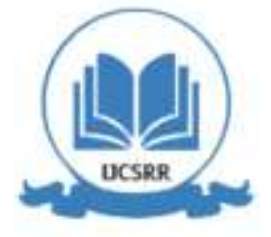

www.ijcsrr.org

Bronchial Asthma: It was studied that hygiene standards which are higher will modulate the development of immune system, which in turn might increase the risk of Bronchial Asthma [23]. The decrease in incidence of H. pylori infection explains increase in prevalence of allergic diseases. Some studies have supported the inverse association between H. pylori infection and asthma. But some studies did not support this conclusion. In a study done by [22] on around 14900 patients the evidence between inverse association between H. pylori and asthma is weak. A study done by group of people from Switzerland it was shown that we can prevent allergic airway disease by $\mathrm{H}$. pylori. Contrast to the above study, another study from Dutch confirmed the association between H. pylori and allergic rhinitis, wheezing, physician- diagnosed asthma [24]. Baes on the different studies we found online, there is no strong correlation between H. pylori and asthma.

Deficiency of Iron: A study conducted by [25] says that infection from H. pylori may be associated with iron deficiency in children. Another study done by [26] says that concentrations of hemoglobin and ferritin were low in H. pylori infected children. The levels of serum $\mathrm{Fe}$ and ferritin and their mean levels for $\mathrm{H}$ pylori negative tested people are higher than people who tested positive.

\section{SOURCES OF H. PYLORI INFECTION AND TRANSMISSION}

In children the most common possibility of transmission is day care centers, or for the adults, from the places where personal contact with other people are common. In a study done on children comparing different situations, it was found that children who spend more with parents got H. pylori instead of the kids who are in kindergarten. Child to child transmission is shown as very low possibility [27]. There are multiple possibilities like oral-oral and fecal-oral etc., and transmission via drinking water and other environmental sources [28]. Transmission can happen from one individual to other, and in children from parent to child or via environment. Some studies were conducted on this transmission factor and figured that studies support both intrafamilial and outside of family transmissions [28]. [29] has identified that fingerprints in $76 \%$ of the children matches with at least one family member with high rate of identity as of mother than father.so mother to child transmission rate considered to happened more in case of $\mathrm{H}$. pylori infection. And it has been proven evident that mothers infected will transfer it to kids in most cases [31,32,33]. Some studies are done on the potential family member transmission [34,35]. [32] figured that presence of siblings who are infected with H. pylori is a risk factor for infection in the children. Another factor that contributes to this infection is high income family see a lower rate of infections compared to medium and low income families which is $37 \%$ vs $48 \%$ [36].The prevalence is also higher in older age groups and also children living in overcrowded houses which is 34\% [37]. The inverse correlation between family income and seropositivity is found to be very strong [33].The children whose parents are illiterate has also seen high rate of infection, and also illiterate mothers living in deprivation areas are also seen with high rate of occurrence of infection [31]. Another study proved that in high income countries, mothers are important source of infection than infected sibling and vice versa in low income countries [38,39]. Another important factor is breastfeeding. some studies have proved that breast feeding has the preventive effect [40]. But some other studies proved are not able to prove this [32]. In a study done by [40] on 327 Turkish people reported an OR of 0.22 and another study by [41] reported an OR of 2.5 among 940 kids that were breast fed. Some studies in the recent fays have also proved that even in some developing countries with poor standard of living, has seen reduction in H. pylori infection [20]. In a study from Turkey the prevalence is $78 \%$ in 1990 and $66 \%$ in 2000 .

\section{PREVENTION AND TREATMENT FOR H. PYLORI}

A paper of review by Choi [42] from Korea published studies on H pylori infection prevention and prevention of gastric cancer. These studies focused on prevention of metachronous cancer following by removal of early gastric cancer in Korea and Japan. This review paper by Choi also considered publications that focused on incident rate of cancer in subjects with treated and untreated peptic ulcer cohorts. It was concluded that no paper has shown sufficient support for the prevention of gastric cancer by $\mathrm{H}$ pylori eradication in general population. Another study done by [43] has shown that Amoxicillin Raft system has proven to show better results in treating $\mathrm{H}$ pylori infection. A study article from Korea [44] is more optimistic, which was conducted on 2089 adults that have undergone endoscopic resection of low-grade gastric neoplasia, high-grade neoplasia, and invasive neoplasia. The incidence was 10.9 cases per 1000 per year cases of metachronous gastric cancer.

Another paper of systematic review [45, 46] conducted on screening which is cost effective for gastric cancer and premalignant lesions. These studies show that for gastric cancer prevention there are several options that can be adopted. Screening of $\mathrm{H}$ pylori 


\section{International Journal of Current Science Research and Review}

ISSN: 2581-8341

Volume 03 Issue 12 December 2020

DOI: 10.47191/ijesrr/V3-i12-05, Impact Factor: 6.595

IJCSRR@ 2020

WwW.ijcsrr.org

with treatment of positive cases to prevent normal gastric mucosa evolution to premalignant lesions and to invasive cancers, or in patients with premalignant lesions, endoscopic surveillance to allow detection of lesions before they can become cancer.

Some prevention precautions need to be taken in children too as they are more prone to this infection than adults. Some of them are malnutrition needs to be addressed [47]. Poor standard of living, crowded families, improper food habits, gastrointestinal infections, low quality of education to parents are the risk factors for $\mathrm{H}$ pylori infection.

\section{CONCLUSION}

There are some articles each year that directly focus on desirability of public health interventions to limit $\mathrm{H}$ pylori infection. There is a good progress these days in understanding among people about the prevalence of $\mathrm{H}$ pylori in different communities and it leading to cancer and peptic ulcer. Some studies support that $\mathrm{H}$ pylori infected mothers and siblings are primary source of $\mathrm{H}$ pylori infection transmission in children. Washing hands thoroughly, drinking water from safe source, of filtered water, and eating food from which is properly prepared in terms of cleanliness or nutrients are important steps to prevent this infection. And more important education children and adults about the infection is also great step towards preventing spread and occurrence of disease.

\section{REFERENCES}

1. Ernst PB, Gold BD. Helicobacter pylori in childhood: new insights into the immunopathogenesis of gastric disease and implications for managing infection in children. J Pediatr Gastroenterol Nutr. 1999; 28:462-73.

2. Thung I, Aramin H, Vavinskaya V, et al. The global emergence of Helicobacter pylori antibiotic resistance. Aliment Pharmacol Ther. 2016; 43:514-533.

3. Fock KM, Ang TL. Epidemiology of Helicobacter pylori infection and gastric cancer in Asia. J Gastroenterol Hepatol. 2010; 25: 479- 486.

4. O'Connor A, O'Moráin C. Helicobacter pylori infection in Europe: current perspectives. Expert Rev Gastroenterol Hepatol. 2013; 7: 541- 548.

5. Krueger W, Hilborn E, Converse R, Wade T. Environmental risk factors associated with Helicobacter pylori seroprevalence in the United States: a cross-sectional analysis of NHANES data. Epidemiol Infect. 2015; 143: 2520- 2531.

6. Inoue M. Changing epidemiology of Helicobacter pylori in Japan. Gastric Cancer. 2017; 20: 3- 7.

7. Handt LK, Fox JG, Stalis IH, et al. Characterization of feline Helicobacter pylori strains and associated gastritis in a colony of domestic cats. J Clin Microbiol. 1995; 33:2280-9.

8. Grubel P, Hoffman JS, Chong FK, et al. Vector potential of houseflies (Musca domestica) for Helicobacter pylori. J Clin Microbiol. 1997; 35:1300-3.

9. Klein PD, Graham DY, Gaillour A, et al. Water source as a risk factor for Helicobacter pylori infection in Peruvian children. Lancet. 1991; 337:1503-6.

10. Staat MA, Kruszon-Moran D, McQuillan GM, et al. A population-based serologic survey of Helicobacter pylori infection in children and adolescents in the United States. J Infect Dis. 1996; 174:1120-3.

11. Ernst, P. B., and B. D. Gold. 2000. The disease spectrum of Helicobacter pylori: the immunopathogenesis of gastroduodenal ulcer and gastric cancer. Annu. Rev. Microbiol. 54:615-640

12. Kuipers, E. J. 1999. Review article: exploring the link between Helicobacter pylori and gastric cancer. Aliment. Pharmacol. Ther. 13:3-12.

13. Kuipers, E. J., J. C. Thijs, and H. P. Festen. 1995. The prevalence of Helicobacter pylori in peptic ulcer disease. Aliment. Pharmacol. Ther. 9(Suppl. 2):59-69

14. Graham, D. Y., L. C. Alpert, J. L. Smith, and H. H. Yoshimura. 1988. Iatrogenic Campylobacter pylori infection is a cause of epidemic achlorhydria. Am. J. Gastroenterol. 83:974-980.

15. Marshall, B. J., J. A. Armstrong, D. B. McGechie, and R. J. Glancy. 1985. Attempt to fulfil Koch's postulates for pyloric Campylobacter. Med. J. Austr. 142:436-439.

16. . Morris, A., and G. Nicholson. 1987. Ingestion of Campylobacter pyloridis causes gastritis and raised fasting gastric pH. Am. J. Gastroenterol. 82:192-199. 
ISSN: 2581-8341

Volume 03 Issue 12 December 2020

DOI: 10.47191/ijcsrr/V3-i12-05, Impact Factor: 6.595

IJCSRR@ 2020

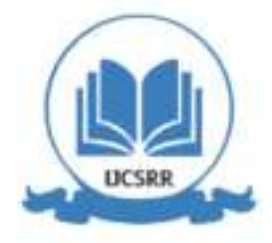

www.ijcsrr.org

17. Sobala, G. M., J. E. Crabtree, M. F. Dixon, C. J. Schorah, J. D. Taylor, B. J. Rathbone, R. V. Heatley, and A. T. R. Axon. 1991. Acute Helicobacter pylori infection: clinical features, local and systemic immune response, gastric mucosal histology, and gastric juice ascorbic acid concentrations. Gut 32: 1415-1418.

18. Granstrom, M., Y. Tindberg, and M. Blennow. 1997. Seroepidemiology of Helicobacter pylori infection in a cohort of children monitored from 6 months to 11 years of age. J. Clin. Microbiol. 35:468-470.

19. Malaty, H. M., D. Y. Graham, W. A. Wattigney, S. R. Srinivasan, M. Osato, and G. S. Berenson. 1999. Natural history of Helicobacter pylori infection in childhood: 12-year follow-up cohort study in a biracial community. Clin. Infect. Dis. 28:279-282

20. Perez-Perez, G. I., R. B. Sack, R. Reid, M. Santosham, J. Croll, and M. J. Blaser. 2003. Transient and persistent Helicobacter pylori colonization in Native American children. J. Clin. Microbiol. 41:2401-2407.

21. Malaty, H. M., L. Engstrand, N. L. Pedersen, and D. Y. Graham. 1994. Helicobacter pylori infection: genetic and environmental influences. A study of twins. Ann. Intern. Med. 120:982-986

22. Wang Y, Bi Y, Zhang L, Wang C. Is Helicobacter pylori infection associated with asthma risk? A meta-analysis based on 770 cases and 785 controls. Int J Med Sci. 2012; 9:603-610.

23. Yucel O. (2014). Prevention of Helicobacter pylori infection in childhood. World journal of gastroenterology, 20(30), 10348-10354. https://doi.org/10.3748/wjg.v20.i30.10348

24. Holster IL, Vila AM, Caudri D, den Hoed CM, Perez-Perez GI, Blaser MJ, de Jongste JC, Kuipers EJ. The impact of Helicobacter pylori on atopic disorders in childhood. Helicobacter. 2012;17:232-237

25. Helicobacter pylori-associated hypochlorhydria in children, and development of iron deficiency. Harris PR, Serrano CA, Villagrán A, Walker MM, Thomson M, Duarte I, Windle HJ, Crabtree JE J Clin Pathol. 2013 Apr; 66(4):343-7.

26. Helicobacter pylori status in family members as risk factors for infection in children. Kivi M, Johansson AL, Reilly M, Tindberg Y Epidemiol Infect. 2005 Aug; 133(4):645-52.

27. Iron status and Helicobacter pylori infection in symptomatic children: an international multi-centered study. Queiroz DM, Harris PR, Sanderson IR, Windle HJ, Walker MM, Rocha AM, Rocha GA, Carvalho SD, Bittencourt PF, de Castro LP, Villagrán A, Serrano C, Kelleher D, Crabtree JE PLoS One. 2013; 8(7):e68833.

28. Axon, A. (2014), Helicobacter pylori and Public Health. Helicobacter, 19: 68-73. https://doi.org/10.1111/hel.12155

29. Schwarz S, Morelli G, Kusecek B, Manica A, Balloux F, Owen RJ, Graham DY, van der Merwe S, Achtman M, Suerbaum S. Horizontal versus familial transmission of Helicobacter pylori. PLoS Pathog. 2008; 4:e1000180.

30. Konno M, Yokota S, Suga T, Takahashi M, Sato K, Fujii N. Predominance of mother-to-child transmission of Helicobacter pylori infection detected by random amplified polymorphic DNA fingerprinting analysis in Japanese families. Pediatr Infect Dis J. 2008;27:999-1003

31. Yücel O, Sayan A, Yildiz M. The factors associated with asymptomatic carriage of Helicobacter pylori in children and their mothers living in three socio-economic settings. Jpn J Infect Dis. 2009; 62:120-124.

32. Kivi M, Johansson AL, Reilly M, Tindberg Y. Helicobacter pylori status in family members as risk factors for infection in children. Epidemiol Infect. 2005; 133:645-652.

33. Yilmaz E, Doğan Y, Gürgöze MK, Unal S. Seroprevalence of Helicobacter pylori infection among children and their parents in eastern Turkey. J Paediatr Child Health. 2002; 38:183-186.

34. Thomas JE, Dale A, Harding M, Coward WA, Cole TJ, Weaver LT. Helicobacter pylori colonization in early life. Pediatr Res. 1999; 45:218-223.

35. Urita Y, Watanabe T, Kawagoe N, Takemoto I, Tanaka H, Kijima S, Kido H, Maeda T, Sugasawa Y, Miyazaki T, et al. Role of infected grandmothers in transmission of Helicobacter pylori to children in a Japanese rural town. J Paediatr Child Health. 2013; 49:394-398.

36. Zhang Y, Li JX. [Investigation of current infection with Helicobacter pylori in children with gastrointestinal symptoms] Zhongguo Dang Dai Er Ke Zazhi. 2012;14:675-677

37. Ozen A, Furman A, Berber M, Karatepe HO, Mutlu N, Sarıçoban HE, Büyükgebiz B. The effect of Helicobacter pylori and economic status on growth parameters and leptin, ghrelin, and insulin-like growth factor (IGF)-I concentrations in children. Helicobacter. 2011;16:55-65 


\section{International Journal of Current Science Research and Review}

ISSN: 2581-8341

Volume 03 Issue 12 December 2020

DOI: 10.47191/ijcsrr/V3-i12-05, Impact Factor: 6.595

IJCSRR@ 2020

38. Rothenbacher D, Winkler M, Gonser T, Adler G, Brenner H. Role of infected parents in transmission of helicobacter pylori to their children. Pediatr Infect Dis J. 2002;21:674-679

39. Parsonnet J, Shmuely H, Haggerty T. Fecal and oral shedding of Helicobacter pylori from healthy infected adults. JAMA. 1999;282:2240-2245

40. Ertem D, Harmanci H, Pehlivanoğlu E. Helicobacter pylori infection in Turkish preschool and school children: role of socioeconomic factors and breast feeding. Turk J Pediatr. 2003;45:114-122

41. Rothenbacher D, Bode G, Brenner H. History of breastfeeding and Helicobacter pylori infection in pre-school children: results of a population-based study from Germany. Int J Epidemiol. 2002;31:632-637

42. Choi IJ. Current evidence of effects of Helicobacter pylori eradication on prevention of gastric cancer. Korean J Intern Med 2013; 28:525-37.

43. Kamsali, Akhil; et al. Development and Optimization of Amoxicillin Floating Raft System to effectively treat Helicobacter pylori infection. Ars Pharm, 61(3): 163-168 (2020). http://dx.doi.org/10.30827/ars.v61i3.13718

44. Bae SE, Jung HY, Kang J, et al. Effect of Helicobacter pylori eradication on metachronous recurrence after endoscopic resection of gastric neoplasm. Am J Gastroenterol 2014; 109:60-7.

45. Areia M, Carvalho R, Cadime AT, Goncalves FR, Dinis-Ribeiro M. Screening for gastric cancer and surveillance of premalignant lesions: a systematic review of cost-effectiveness studies. Helicobacter 2013; 18:325-37.

46. Ravi Manne,Snigdha Kantheti,Sneha Kantheti,(2020),"Classification of Skin cancer using deep learning, ConvolutionalNeural Networks - Opportunities and vulnerabilities- A systematic Review", International Journal for Modern Trends in Science and Technology,ISSN: 2455-3778,Vol.06, Issue 11,pp. 101-108. https://doi.org/10.46501/IJMTST061118

47. Queiroz DM, Rocha AM, Crabtree JE. Unintended consequences of Helicobacter pylori infection in children in developing countries: iron deficiency, diarrhea, and growth retardation. Gut Microbes. 2013;4:494-504

48. Kusters JG, van Vliet AHM, Kuipers EJ. Pathogenesis of Helicobacter pylori infection. Clin Microbiol Rev. 2006; 19(3):449-90.

49. https://www.shomusbiology.com/

Cite this Article: Rahul Rao, Tanya Datta, Shivali Sharma (2020). Helicobacter Pylori Infection: Causes, Diagnosis and Treatment. International Journal of Current Science Research and Review, 3(12), 224-229 